$\mathbb{T}$ periodica polytechnica

\author{
Social and Management Sciences \\ $17 / 2(2009) 73,78$ \\ doi: 10.3311/pp.so.2009-2.03 \\ web: http://www.pp.bme.hu/so \\ (c) Periodica Polytechnica 2009
}

RESEARCH ARTICLE

\section{Office working environment development - Introduction of a Concrete Empirical Research}

\author{
Edit Németh
}

Received 2010-01-05

\begin{abstract}
In our modern and extremely changing world firmness in market competition, maintaining market position and/or their realization according to strategic purposes are in the focus of corporate decisions.

At the same time, it is also salient for corporate executives that choosing the adequate strategy is not sufficient in itself. Carrying out the strategy successfully requires a new way of approach to corporate control of managers, which should be supported by the design of office working environment, and the arrangement of corporate units and employees. In all these ergonomics - which provide healthy, comfortable working environment ensuring well-being of employees and working conditions supporting efficient work - can give corporate executives a kind of guidance to plan adequate corporate environment. Besides planning ergonomic working environment, the conception of office planning influences intellectual work, life of the corporation, work efficiency, communication within the corporation, team work, and individual performance to a great extent.

Further on, I present an empirical research, by means of which I have developed an office conversion method in order to reveal cultural, communicational, work organizational factors of various organizations and which is by all means recommended to be taken into consideration in the course of designing an office environment supporting efficient work.
\end{abstract}

\section{Keywords}

marketing · internal marketing · organizational development . ergonomics

\section{Edit Németh}

Department of Ergonomics and Psychology, BME, 1111 Budapest, Egry J. u. 1., Hungary

e-mail: edit@erg.bme.hu

\section{Theoretical background of the study}

1.1 A new kind of marketing strategic approach

In the 21 st century a number of new strategic approaches appeared, in the course of which a number of technological, technical novelties such as the Internet, wireless communication, cell phones, and video conferences, etc. are serious challenges to corporations. In the course of the competition none of the corporations can afford to neglect these technologies. As Kotler puts it [11, pp. 7]: 'the Internet, technology, and globalization have created the New Economy. The old economy is founded on the way of thinking applied in the management of the manufacturing industry whereas the new economy is based on handling information and controlling information industry. In the new economy organizations having the best information- and newsgathering system can rely on success.' In answer to the new challenges a new marketing strategy and a new way of thinking should be introduced and applied.

Holistic marketing conception can be of help to corporations with making and realizing the new marketing strategy. According to Kotler [11, pp. 148] the main point of holistic marketing conception is that 'organizations should become customer-oriented', which helps to maintain competitiveness of the organization in the course of a constantly changing market competition. Holistic marketing structure according to Kotler [11. pp. 35] 'gives instructions to change the present organizational structure' as well. Four factors of holistic marketing are Relationship Marketing, Integrated Marketing, Internal Marketing and Socially Responsible Marketing. Internal Marketing should be highlighted from among them, which emphasizes the importance of marketing activities within the corporation, i.e. marketing activities within the corporation are almost more important than those outside the corporation. The task of Internal Marketing is 'ensuring that everyone in the organization embraces appropriate marketing principles, especially senior management. Internal marketing is the task of hiring, training, and motivating able employees who want to serve customers well.' [13. pp. 56]. 
1.2 Relations between office planning conceptions and working habits

Corporate executives have to be fully aware how certain office planning conceptions can influence and improve communication within the company, the employees' cooperation, and individual performance in order to be able to form their corporation according to the challenges of the new corporate control, technology, and sales with the help of new marketing strategies.

\section{Office planning conceptions and their characteristics:}

Cell offices have been typical since the end of the 19th century. Jobs requiring large attention were done there and stress was laid on monotonous work. Continuous exchange of information between colleagues is possible in offices for 3-4 people. Individual spaces and an atmosphere of intimacy can be formed in the offices. Only a small number of employees' requirements are to be taken into consideration when the environmental factors of cell offices are formed, so considerable satisfaction can be reached.

Open offices, which efficient work was tried to be supported with, appeared after World War 2. The aim of planning open offices is to have employees doing similar work in the same office, which is not only cost-saving but also makes control for managers comparably simple and moreover, employees can easily communicate with each other. Several employees' (at least 12-20 people) requirements have to be taken into consideration when planning an open office (heating, air-conditioning, lighting), so it is difficult to assure an individual character and space to them.

Easily variable offices, project offices have appeared since the 1990s as ways of work have changed. A single person does not only do a single activity any more but has a complex task and open offices for a number of people (30-40) do not provide an ideal solution for all these. Continuous communication and thinking in projects have brought spaces supporting formal and informal communication and project rooms into being. Stone and Luchetti in their article, 'Your office is where you are' describe it as follows: 'Workplace is the centre of a communicational net'. Different individual spaces can appear in these spaces again but the problem is that physical environmental factors of rooms have to be easily variable and flexible according to easily variable offices.

Today, as home offices, i.e. working far from the office, have appeared, at the same time a new type of office plan appeared in office buildings, the share-desk system. The share-desk system can only be used in special jobs, such as counsellors, accountants, software engineers, sales managers, and comfortable working environment has to be provided for employees working in the office occasionally. One of the advantages of the plan is that the number of workstations decreases, several employees can use a single workstation. However, its drawback is that employees' personal space is limited to a mobile office trolley. The function of forming a collectivity is taken over by various formal and informal communicational spaces.

In the life of an organization the office plan conceptions described above are present together according to the work character of particular organizational units (e.g. intellectual work, team work, etc.), their communicational habits, employees' individual requirements and their preferences.

A basis of my Ph.D. study is the recognition that a corporation, due to responding to challenges of the market, performs not only strategic, organizational changes but they also change office environment according to organizational changes, at best.

My purpose is to work out a research method that beyond traditional principals of ergonomics (ergonomical desks, office chairs, lighting, air-conditioning, etc.) furthers the improvement of the efficiency of the whole organization. The following model of working conditions improvement furthering individual and team work of employees, which I worked out and introduce below, supports the application of the method. To be able to apply the method efficiently we need a complex attitude that indicates and makes use of information belonging to particular factors by taking ergonomical, organizational, and communicational factors into consideration and recognizing organizational features. During the application of the research method considerable stress should be laid on getting to know the operation, daily routine, and the way of communication of particular departments within organizations. In the course of my empirical study to plan the arrangement of offices and furniture, I started from the three main factors stated by Becker [3, pp. 10], such as:

- corporate culture,

- type and requirements of employees,

- technological needs.

\section{Introduction of the empirical study}

\subsection{Drafting the research problem}

A customer-oriented company working in food-industry (bottling beverages) has worked out a competition strategy that suits environmental challenges at the best. They have changed their internal processes according to it, some work processes have also changed, and in the meantime the number of employees has been constantly increasing.

Meanwhile, new functions have occurred, such as new kind of office, production and storage functions. During office work four types of mental activities had to be provided: work requiring considerable extent of concentration; contact with incompany customers; production or storage process support, and sales - mobile work.

The purpose of the study is to come up with suggestions of inside office plans and changes according to internal processes of the organization, in which besides traditional aspects of ergonomics described above office plan conceptions suiting the new way of work and supporting effective work are taken into consideration in an integrated way. 


\subsection{Proposed methodology of the research}

Incurring requirements during planning the office environment of an organization can be surveyed from three main aspects such as the point of view of top managers, managers, employees, and experts. In the first phase of the study, on the basis of Veres-Hoffmann-Kozák (2006)[23] and Babbie (1999)[2] for the selection of research methodology after processing secunder information we planned to uncover problems and requirements with the application of three main research methods at the same time.

The research methods are based on one another, so first of all we intended to get a detailed picture of the operations of the corporation and the problems to be recognized applying field observation method. The next one is the field observation method, during which we hoped to complete and support the problems recognized by getting to know the way of thinking of top managers and managers, preparing personal interviews, so further information can be gained about the life of the organization. The third main aspect of the research is the knowledge of employees' opinion, demands, and requirements. We planned to apply the online questionnaires method. In order to compose reflective questionnaires we should compile the problems and the possible sollutions recognized during field observation method and managerial interviews.

In the second phase, after evaluating the outcome of observations, managerial interviews and online questionnaires and with the help of the creation of standard workstations room size needed for particular units can be defined and various office arrangement plans can be made. Managers and experts choose the final version on the bases of the conceptions worked out by us. Employees are also informed of the outcome of the research and the final layout plan of the office.

In the third phase, after moving in, we intended to collect experiences of the new plan via field observation and the usage of particular appliances were taught on a so-called ergonomics day. We suggested applying the focus groups method to decrease opposition to the new office plan.

Fig. 11 summarizes particular stages and process segments.

\subsection{Introduction of effective methods of the empirical re- search}

At the food-industrial company on the basis of development of working environment model we gathered secondary information, such as the organizational structure, number of employees and the ground-plan. Having analyzed the disposable data we planned the primary inquiry, in the course of which we worked with the aforementioned qualitative and quantitative methods in the first phase of the inquiry in order to get to know the current and future operation of the organization.

Three pre-compiled lists were applied at all organizational units during land observation and expert ingress, which contained:
Tab. 1. Methods Used in the course of ergonomic survey. Source: Own research

\begin{tabular}{ll}
\hline Method of research & Sample size \\
\hline Observing the land (professional ingress) & 5 working days \\
Managerial interview & With 26 managers \\
Inquiry of employees by questionnaires & $\begin{array}{l}\text { Proportion of return: } 50 \% \text { (142 } \\
\text { employees) }\end{array}$ \\
\hline
\end{tabular}

global checking list, in which we examined the social premises of the given organizational unit (dining rooms, rest rooms, smoking areas, dressing rooms, lavatories and other premises),

environment checking list, in which we examined the layout, furniture and working environment (lighting, climatic factors, noise, colours), and

evaluation of computerized workplaces aiming at certain peripheries of computerized workplaces (monitor, keyboard, mouse, $\mathrm{PC}$ case, printer, scanner etc).

Expert ingress was supplemented with managerial interviews, which covered the following main subjects:

- current and future headcount of the organizational unit and its status,

- work schedule of employees of the organizational unit and type of arrangement

- problems in connection with the layout, physical environment, furniture and appliances of the organizational unit,

- surveying habits of communication inside the organization,

- surveying habits of keeping in touch of the organizational unit inside the company

- other remarks, observations.

Involving of employees into the survey was carried out with online questionnaires, which mainly focused on employees' satisfaction or reasons of satisfaction or dissatisfaction regarding shaping the current workplace and mapping employees' needs. After giving a short introduction of the survey, the questionnaire contained 6 main topics (40 questions):

- workplace and its equipment (habits of storage, needs for utensils),

- shaping the physical environment (office premises, natural and articial lighting of working area, air-conditioning factors, load of noise),

- layout of workplace (personal area, shaping the workplace, medical complaints),

- relation of workplaces (communication, layout of workplaces),

- social premises,

- demographic data (position, organizational unit). 
Fig. 1. Phases of inquiry of development of working environment. Source: Own model

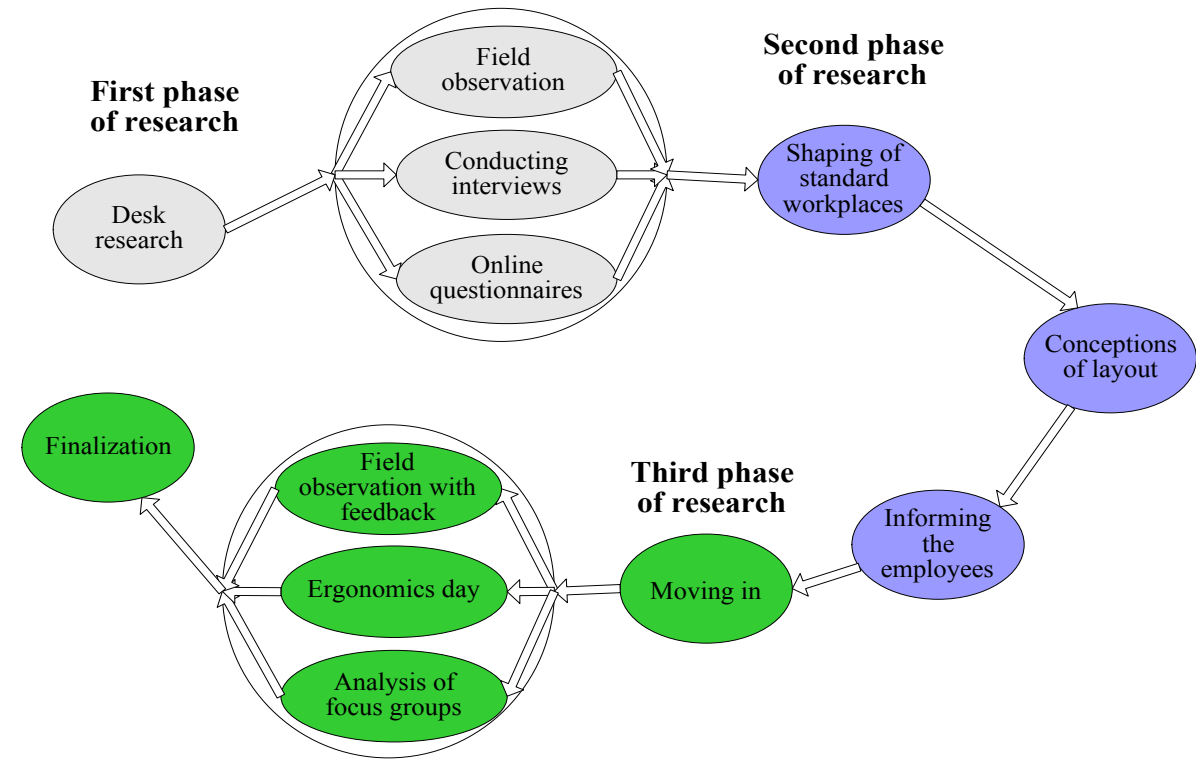

\subsection{Main statements of empirical research}

According to the methods described above, employees' problems in connection with office premises were revealed with the help of online questionnaires that were filled in by half of employees (142 people), of which $21.8 \%$ had a cell office, $71 \%$ worked in a open office and $7.2 \%$ of respondents spent $90 \%$ or even more of their time outside the office or office building. (These filling in ratios fit the employees' positions within the organization so on the basis of received results opinions concerning the layout can be generalized on the whole organization.)

Firstly, we analyzed main outcome of the research on the level of individuals, then organizational units, finally on organizational level. Therefore, at first we defined typical work places on the basis of individual opinions, requirements, then we determined space requirements of single organizational units. Finally, we established layout versions of organizational units within the company, taking flow of information and communicational habits into account.

\subsubsection{Findings in connection with individual requirements}

According to data of online questionnaires and field observation it turned out that two thirds of those inquired were not satisfied with the physical surroundings (lighting, noise, airconditioning). (We applied a five-grade scale, in which grade1: not sufficient at all, grade5: totally sufficient.)

It is salient in Fig. 2 that according to one fourth of those inquired natural light is little in offices, so it should be taken care of in any case when planning the layout of new offices. To provide natural light flowing into the building, as many windows should be built in as possible. The largest number of workers complained about air-conditioning, which was graded just sufficient due to poor working of air-conditioners (they do not provide comfortable temperatures, some people are cold, some hot) and that they cannot be controlled. Workers also listed here

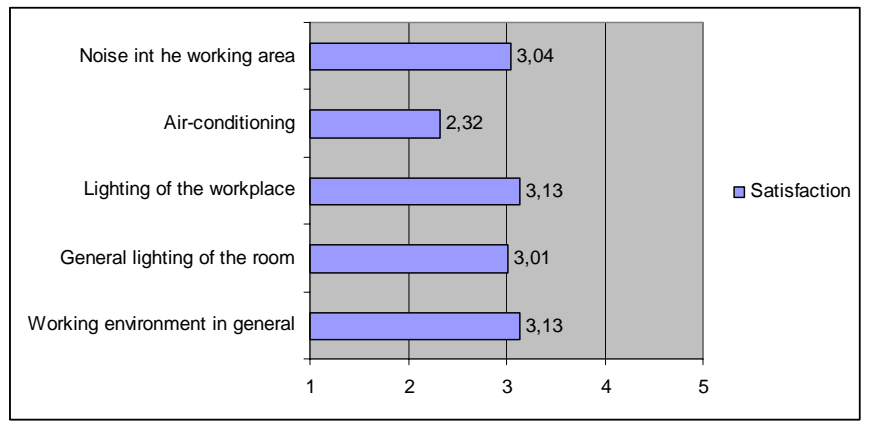

Fig. 2. Respondent satisfaction regarding factors of physical environment. Source: Own research

that ventilators did not work properly because the current system was planned for the old large open plan spaces and changes that occured in the meantime were not taken into consideration, so they ran out fresh air by the afternoons and workers became tired, made more mistakes, their work efficiency decreased.

During our research we found out that new forms of work within the company cannot be properly supported by ten-fifteenyear-old furniture (desks, office chairs, storage shelves) any more. According to workers office chairs are worn out and the sizes of work and storage tops are convenient to little extent. Furthermore, they say that neither the environmental plan nor the layout support work adequately. Therefore, considering 'traditional' aspects of ergonomics we thought necessary to choose new furniture that suit work features.

The location of certain organizational units was examined after the general analysis of environmental factors. On the basis of it we can say that there is a higher scale of dissatisfaction in connection with shaping physical working factors in those units where employees are crammed (per capita $\mathrm{m}^{2}$ is very low, under $5-7 \mathrm{~m}^{2}$ ). It can generally be stated that in those offices where several kinds of activities are going on, such as: jobs requiring 
a high level of concentration, making phone calls or receiving clients, load of noise put on employees is high.

\subsubsection{Findings regarding the creation of typical workplaces}

We also found out that offices today are overburdened, the situation in some departments is almost intolerable. (We found offices where per capita $\mathrm{m}^{2}$ is as small as 3-4 $\mathrm{m}^{2}$.) In the course of the survey and field observations we could hardly find organizatonal units where the distance between employees was as high as $150 \mathrm{cms}$ in all cases.

The company has outgrown the office space available due to current and future increase in workforce, and new functions and requirements occurring in the organization, so we had to take a survey of the possibilities to make new offices. We suggested to increase the size of offices available with $900 \mathrm{~m}^{2}$ by optimizing the current layout and making new offices.

Based on the survey of individual requirements, field observation and managerial interviews, we described six kinds of typical workplaces, such as:

- director's office,

- manager's room,

- secretary, assistant,

- operative workplace with facilities for having visitors,

- operative workplace,

- mobile workplace.

Along with describing typical workplaces, we determined the resource and space requirements of each type. When we determined space requirements of single organizational units we also took into consideration 'silent' and 'noisy' zones according to features of work and we optimised their space requirements on its basis.

\subsubsection{Layout conceptions}

After determining space requirements of organizational units during the survey of work processes those answering online questionnaires also supported statements of managerial interviews, such as personal meetings play an important role in the life of an organization, so it is important that workers are able to contact their colleagues easily during their work and that organizational units are easily accessible. (In online questionnaires those interviewed were slightly satisfied with the accessibility of organizational units and the environmental layout supporting it.)

By means of research methods we recognised that the number and layout of formal and informal comunicational spaces provided for employees are not adequate, so in the course of replanning kitchenettes, rest areas should be made near their offices, where workers can relax - to the necessary extent - increasing work efficiency when they get back to work.
By drawing flow of information and communicational network we defined which organizational units are connected closely to one another. Therefore, for the sake of the best possible layout we took into consideration that employees working in the same line should be close to one another (10-20 m distance), as being farther from one another would decrease the quality of communication or even stop it. During the arrangement of organizational units we considered which units are closely connected with production, plant, and warehouse, etc..

Having summarized the results of examinations we drew three main conceptions in connection with shaping the office, which were opined and graded by the management, then finally they made a decision about the final version. More communication channels were used to inform employees. Electronic letters were sent to them, in which we informed them about results of examination, and we made local ingress where alteration had taken place, moreover, remarks and problems from the employee side were collected. Alteration of offices is still in process, then we are going to hold a so-called "Ergonomy day" when the whole occupancy has finished. The purpose of it is that employees would learn to use their workplaces in an ergonomic way and augment their efficiency at work by possibilities provided by working environment.

\section{Further output and dimensions of the survey}

Although the survey has not finished yet we can - by all means - draw the conclusion that by applying different inquiry methods together and with the support of a team including different professional fields we could compile a much more careful and complex solution suggestion pack for managers to convert working conditions of the company. With our work we were able to influence not only corporate culture and operations but employees' feeling of comfort was improved as well. As a result employees' loyalty towards the company became stronger.

In the next phase, six months after total office conversion, when workers are acquainted with and use their new offices and equipments, I will make a survey of the acceptance of the new conditions, changes in efficiency of corporate activities and economic success together with the survey methods applied earlier.

A starting point of my Ph.D. survey, namely internal marketing and the importance of human resource are inevitable to sustain competetiveness, is not new-fangled. However, the study of how companies react to different challenges in the market - with organizational development and a conception about transforming the workplace - is not a typical characteristic yet. Accepting the conception, its complex interpretation and optimal feasibility are still in their infancy in Hungary. When talking about improving working conditions, then we develop such a supportive skill by utilizing two practicable disciplines, which has an impact on the performance of the company by all means.

On the basis of the utilized theoretical models and findings of empirical survey we compiled the „Model of working environment-development" that may seem new and special. Its 
components and connections are introduced in Fig. 3

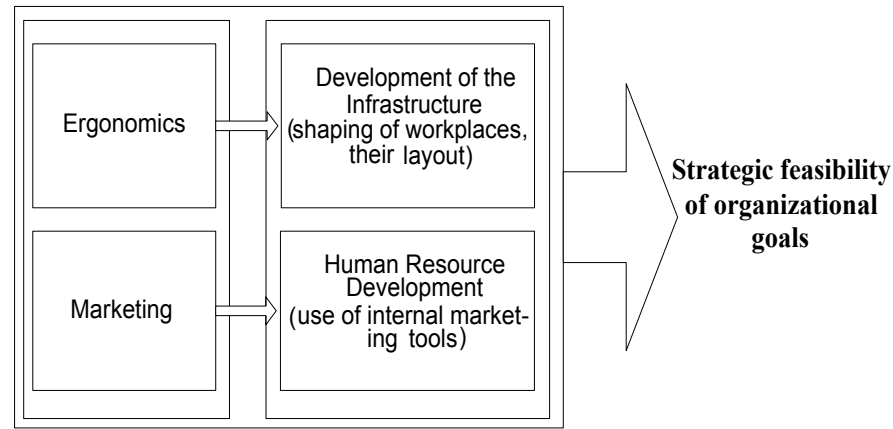

Fig. 3. Model of working environment-development Source: Own model

Finally we can state that a corporation can carry out their strategy if they harmonise their work processes. The bridge (or link) between the two areas of science (ergonomics, marketing) I have also applied is the worker himself. For the company 'permanent relationship with employees becomes a huge asset as people link the company to partners' [24, pp. 186]. In order to make employees stay at the company for a long time and to increase corporate assets with their expertise, creating comfortable and effective workplaces that support work can be used as a positive influential factor. With the application of adequate inner marketing tools and the best possible recognition of organizational purposes we can make employees be involved in the implementation of corporate purposes as real corporate assets, i.e. link to the corporation even more and with their loyalty they can also make the company be able to reach even higher performance.

\section{References}

1 Ahmed P, Rafig K, Internal Marketing: Tools and Concepts for Customer Focused Management (Chartered Institute of Marketing), Biddles, Norfolk, 2002.

2 Babbie E, A társadalomtudományi kutatás gyakorlata, Balassi Kiadó, Budapest, 1999.

3 Becker F, Offices at Work, Wiley \& Sons, Inc., San Fransisco, 2004.

4 Beckhard R, A szervezetfejlesztés stratégiája és modelljei, Közgazdasági és Jogi Könyvkiadó, Budapest, 1974.

5 Hall E T, Rejtett dimenziók, Gondolat Kiadó, Budapest, 1975.

6 Hercegfi K, Izsó L, Ergonómia, Typotex Kiadó, Budapest, 2007.

7 Hofmeister-Tóth Á, Simon J, Sajtos L, Fogyasztói elégedettség, Alinea Kiadó, Budapest, 2003.

8 Homburg C, Workman J P J, Krohmen H, Marketings Influence Within the Firm, Journal of Marketing, 63(2), (1999), 1-16, DOI 10.2307/1251942.

9 Kotler P, A marketingról. Jönni, látni, gyózni - a piacon., Park Kiadó, Budapest, 2000.

10 _ Marketingmenedzsment. Elemzés, tervezés, végrehajtás és ellenôrzés., Múszaki Könyvkiadó, Budapest, 2002.

11 Kotler P, Marketing managament, Pearson, Upper Saddle River, 2003.

12 Kotler P, Jain D C, Maesincee S, Marketinglépések. Nyereséges növekedés és megújulás a 21. században, Park Könyvkiadó, Budapest, 2003.

13 Kotler P, Keller K L, Marketingmanagement, Pearson, Prentice Hall, Upper Saddle River, 2006.

14 Malhotra N, Marketingkutatás, Múszaki Könyvkiadó, Budapest, 2001.

15 Marmot A, Eley J, Office space planning: designing for tomorrow's workplace, McGraw-Hill, New Yersey, 2000.
16 McKeown, Office Ergonomics, CRC Press, Boca Raton, 2003.

17 Percze C, A vállalat belsố és külső környezete és a megfelelö irodatípus összefüggései - igények és lehetôségek az irodapiacon, Doktori disszertáció, 1995.

18 Peters T J, Waterman R H, A siker nyomában, Kossuth Könyvkiadó, Budapest, 1986.

19 Peczöli I, Szabó G, Flexible office environment: psychological and ergonomical requirements for design landscape office, Periodica Politechnica Social and Management Sciences, 7(2), (1999), 135-150.

20 Scipione P, A piackutatás gyakorlata, Springer Hungarica, Budapest, 1994. 21 Sullivan L, The tall office Building Artistically Considered, Chicago, 1896.

22 Stone P, Luchetti R, Your office is where you are, Harvard Business Manager, 4, (1995).

23 Veres Z, Hoffmann M, Kozák Á, Bevezetés a piackutatásba, Akadémiai Kiadó, Budapest, 2006.

24 Vasné Egri M, Marketingdöntések a fejlett gazdaságokban, Aula Kiadó, Budapest, 2005. 